\title{
Review
}

\section{Chemokines and Chemokine Receptors in susceptibility to HIV-1 infection and progression to AIDS}

\author{
Animesh Chatterjee, Anurag Rathore, Sanjukta Vidyant, Kavita Kakkar and Tapan N. Dhole* \\ Department of Microbiology, Sanjay Gandhi Post Graduate Institute of Medical Sciences, Lucknow, India
}

\begin{abstract}
A multitude of host genetic factors plays a crucial role in susceptibility to HIV-1 infection and progression to AIDS, which is highly variable among individuals and populations. This review focuses on the chemokine-receptor and chemokine genes, which were extensively studied because of their role as HIV co-receptor or co-receptor competitor and influences the susceptibility to HIV-1 infection and progression to AIDS in HIV-1 infected individuals.
\end{abstract}

Keywords: HIV-1 infection, Polymorphism, Chemokine receptor, Chemokines

\section{Introduction}

Human immunodeficiency virus type 1 (HIV-1) is the causative agent of acquired immunodeficiency syndrome (AIDS) in humans. HIV-1 has continued to spread across the globe, despite attempts by the medical and scientific communities to curb the epidemic. After the discovery of HIV as the causative agent of AIDS in 1981, nearly 21 million people have died worldwide and nearly 33.4 million people are living with HIV-1 infection globally. In 2008 alone, 2.7 million people were newly infected with HIV and 2.0 million people have died [1]. In India, adult HIV prevalence is approximately $0.30 \%$, which corresponds to an estimated 2.5 million people living with HIV in the country [2].

AIDS is a complex and long-term chronic disease, triggered by initial infection with HIV-1, which gradually leads to depletion of the CD4-T-lymphocyte cell population, a prelude to immune system collapse. The course of HIV-1 infection varies widely even among in-

\footnotetext{
* Corresponding author: Dr. T.N. Dhole, Department of Microbiology, Sanjay Gandhi Post Graduate Institute of Medical Sciences, Raebareli Road, Lucknow (UP) 226014 India. Tel.: +91 5222668700 , 800; Ext: 4263 (O), 4264 (R); Fax: +91 522 2668100; E-mail: tapandhole@yahoo.co.in.
}

dividuals with similar risk exposure levels [3-5]. There is considerable heterogeneity among individuals in infection susceptibility, in the time required to deplete the CD4 T-lymphocytes population and to develop AIDSdefining diseases [6-8]. However, a small fraction of HIV-1 infected individuals remain both clinically and immunologically healthy for 10 years or more after seroconversion [9-11]. Conversely, the disease of another significant fraction is characterized by an extremely rapid progression to AIDS within 1 year. There are also individuals not infected with HIV-1 who have had repetitive sexual exposure to HIV-1 in extremely highrisk situations, known as exposed uninfected (EUs) [3, 12-15]. Understanding the mechanism that account for slower disease progression and the protection against HIV-1 infection is important for the development of more potent therapeutic regimens and a vaccine.

Although a myriad of social and economic factors strongly influence the HIV-1 pandemic, a possible role of host genetics probably account for a portion of the observed epidemiological heterogeneity in infection susceptibility and in progression rate. Significant studies in the past have demonstrated that genetic polymorphisms in human genes can influence the risk for HIV-1 infection and disease progression [16-19].

Extensive meta-analyses of several large AIDS cohorts have revealed numerous genes which are im- 
plicated in the outcome of HIV-1 infection, leading to the characteristic variability of disease progression seen following HIV-1 infection. The genes that have been identified were called as AIDS restriction genes (ARGs) and are involved in several stages of HIV-1 replication, including viral entry, immune regulation following infection and adaptive immunity to HIV1 [17].

This review summarizes the chemokines and chemokine receptor variants that modulate the susceptibility and progression to AIDS in HIV infected individuals.

\subsection{Chemokines}

Chemokines are a group of small $(\sim 8-14 \mathrm{kDa})$, mostly basic, structurally related molecules that regulate cell trafficking of various types of leukocytes through interactions with a subset of seven-transmembrane, G protein-coupled receptors, whereby several different chemokines can signal through the same receptor. They play a critical role in many pathophysiological processes such as allergic responses, infectious and autoimmune diseases, angiogenesis, inflammation, tumor growth and hematopoietic development [20]. About 40 different chemokines have now been identified in humans. They mainly act on neutrophils, monocytes, lymphocytes, and eosinophils and play a pivotal role in host defense mechanisms [21] They are secreted by a variety of cells types that includes T cells, macrophages, natural killer (NK) cells, $\mathrm{B}$ cells and mast cells, and serve to regulate chemotaxis and adhesion. Once secreted, chemokines attach to other cells via chemokine receptors present on the target cell surface. Eighteen chemokine receptor have been identified, each of which can accept one or more than one chemokine [22]. They are subdivided into four families based on the relative arrangement of cysteine $(\mathrm{C})$ residues, namely $\mathrm{CC}$ ( $\alpha$ chemokines), CXC ( $\beta$ chemokines), C (lymphotactin) and $\mathrm{CX} 3 \mathrm{C}$ (fractalkine) [21]. The chemokines CCL3 (macrophage inflammatory protein-1 (MIP-1 $\alpha$ ) and CCL5 (regulated upon activation, normally T-cell expressed and secreted (RANTES) are natural ligands of CCR5 co-receptor that block entry of non-syncytium inducing (NSI) virions and SDF-1 (stromal derived factor-1) is a ligand for CXCR4 that is used by syncytium inducing (SI) viruses. Discoveries over the past few years have identified a close relationship between chemokines and HIV infection, apart from their well established role in blocking viral entry by binding to their receptors, chemokines have additional role in HIV pathogenesis [20].

\subsection{Chemokine receptor}

The entry of HIV-1 into its target cells is mediated by the viral envelope glycoproteins such as gp120, which binds the cellular receptor CD4, the primary virus receptor. However, HIV-1 also needs co-receptor for entry into the target cells. Different chemokine receptors have been implicated in HIV pathogenesis, CCR5 and CXCR4 are the major co-receptors that are used by nonsyncytium inducing (R5) and syncytium inducing (X4) virions, respectively. CCR5 is the major co-receptor for entry of macrophage-tropic HIV-1 isolates, which has been reported by several groups independently [2325]. Majority of primary HIV-1 isolates are predominantly CCR5 tropic and gradually tend to become CXCR4 tropic during late infection. The CCR5 gene is located in the 3 p21.3 region of the human genome, together with other inflammatory chemokine receptor genes and is expressed on the surface of monocytes, dendritic cells and activated $\mathrm{T}$ cells. Genetic studies have reported various mutations in the promoter and coding region of genes encoding HIV co-receptors and their chemokine ligands, which were associated with resistance to HIV-1 infection and with rapid and slow rate of progression to AIDS [26-28].

\section{C-C chemokine receptor-5 (CCR5)}

\subsection{CCR5 delta 32}

CCR5 delta 32 is a polymorphism in the gene encoding the CCR5 chemokine receptor in which a 32base pair region has been deleted which results in truncation of protein synthesis. Individuals who have two copies of this mutation (i.e. CCR5- $\Delta 32$ homozygous or CCR5- $\Delta 32 / \Delta 32$ ) have non-functional receptors. This non-functionality renders CCR5- $\Delta 32 / \Delta 32$ individuals immune to $\mathrm{R} 5$ strains and they are protected from HIV-1 infection $[19,29,30]$. Individuals who possess one copy of CCR5- $\Delta 32$ and one copy of CCR5wildtype (CCR5- $\Delta 32$ heterozygous or CCR5- $\Delta 32 / \mathrm{wt}$ ) may have altered chemokine receptor activity which results in delayed progression to AIDS [31-33], and CCR5- $\Delta 32$ heterozygous genotype is neither essential nor sufficient for protection against disease progression [34]. However, recent studies has shown that the CCR5- $\triangle 32$ protein in CCR5 deficient individuals may act as a negative modulator of HIV-1 entry by scavenging molecules involved in HIV-1 entry $[35,36]$. The role of the CCR5- $\Delta 32$ mutation on susceptibility and 
resistance to HIV-1 infection has been reported previously by several groups. The frequency of CCR5 delta 32 is found to be $9.6 \%$ in the Spanish [37] and upto $15 \%$ in Caucasians [19]. A study in North Indian population shows the protective allele occurred at a low frequency $(0.95 \%)$ with not a single individual homozygous for the variant (Rathore et al., 2009), and only $1.3 \%$ is present in South Indians [38] and other Asian population too [39]. In contrast, the CCR5 delta 32 allele is virtually absent among native African ethnic group [30]. The marginal presence of the CCR5 delta 32 allele seen in Asian population could plausibly be due to gene flow from Caucasians population.

\subsection{CCR5 promoter}

Single nucleotide polymorphisms (SNPs) in the CCR5 promoter region affect the levels of CCR5 expression and rates of HIV-1 disease progression [26, 40]. Several studies have been carried out to evaluate the association of CCR5 -59029 A/G polymorphism with course of HIV-1 infection. It has been demonstrated that HIV-1 infected person with CCR5-59029 GG polymorphism had slower progression to AIDS [27, 40-42]. In contrast, in Australian population, CCR5 59029 AA homozygotes were found underrepresented in the non-progressors group as compared with other HIV-1 positive groups, suggesting that individuals lacking the homozygous AA genotype would progress to AIDS more slowly [40]. However, a recent study has failed to find any such disease retarding effect of $G$ nucleotide [43] in North Indians, as has been previously reported in London cohort [44], North Indians [45] and White Europeans [46].

There are several studies reporting no association of CCR5-59029 AG polymorphism with susceptibility to HIV-1 infection $[27,45,47,48]$. However, a recent study in North Indians HES individual, CCR5-59029 AG genotype was found to be significantly enriched as has also been reported in Caucasian Exposed Seronegative (ES) individuals [13]. These observations suggest that CCR5-59029 AG may partially be responsible for providing resistance against acquisition of HIV-1 infection.

\subsection{MIP-1 $\alpha P$ (Macrophage Inhibitory Protein-1 $\alpha P$; CCL3L1)}

CCL3L1 is the most potent CCR5 agonist and the strongest inhibitor of infection by R5 HIV-1 strains [49]. The CCL3L1 gene is located on chromo- some 17q11.2, encodes a 93-amino acid preprotein MIP-1alpha. It contains 3 exons and spans about 1.9 $\mathrm{kb}$ [50]. Recently, copy number variations in CCL3L1 have been reported to be linked to the susceptibility to HIV-1 infection, which varies among individuals. [16]. Individuals with $\leqslant 2$ copies of CCL3L1 gene from the median for their population group had a significantly higher risk for acquiring HIV-1, whereas those with $>$ 2 copies above mean had significantly less risk. Moreover, a gene dose lower than the cohort median was associated with increased risk of progressing more rapidly to AIDS and death. Similar findings by Nakajima et al. [51] also reported that average copy number of CCL3L1 in the HIV-1 infected subjects with hemophilia was significantly lower than in control. Furthermore, the subjects possessing 2 or less copies of CCL3L1 had significantly higher risk of acquiring HIV-1 [51]. In contrast to the previous studies, a recent study by Rathore et al. in North Indians found no significant influence of CCL3L1 copy number lower or higher than the median copy number on HIV-1 susceptibility and disease progression [43], as has also been reported previously [52]. Moreover, Nakajima et al. also reported that CCL3L1 copy number variations had no significant effect on the disease progression among the LTNP (Long Term Non-Progressors) subjects, when compared between non-progressors and patients under treatment [51]. Analysis of HIV-infected European individuals also failed to detect any statistically significant association between the distribution of CCL3L1 gene copy number and rate of progression to AIDS [53]. Thus, in the absence of finding any association, it can be speculated that expression of CCL3L1 mRNA may be independent of CCL3L1 gene copy number and may be regulated/influenced by other factors [54].

\subsection{RANTES (Regulated upon Activation, Normal T cell Expressed and Secreted; CCL5)}

RANTES encoded by CCL5 gene is a CC chemokine, located on chromosome 17q11.2-q12, that chemoattracts leukocyte. It plays a critical role in T-lymphocytes activation and proliferation. It is produced principally by CD8+ T-lymphocytes, platelets and epithelial cells $[55,56]$. It is one of the natural ligands for the chemokine receptor CCR5 and potently suppresses in vitro replication of the R5 strains of HIV-1 [56,57]. RANTES acts by blocking binding of the HIV envelope gp120 to CCR5 and by reducing surface levels of CCR5 [58]. 
Several SNPs in the RANTES gene have been reported to influence the natural course of HIV-1 infection by up- or down-regulating RANTES gene activity. The most frequent of those polymorphic sites comprise RANTES - $403 \mathrm{G} / \mathrm{A}$ and RANTES $-28 \mathrm{C} / \mathrm{G}$ in the promoter region and RANTES In1.1 T/C in the first intron region $[59,60]$. Both promoter polymorphism increase RANTES transcription and may delay HIV-1 disease progression [60,61]. Conversely, the RANTES In1.1 C allele seems to decrease RANTES transcriptional activity and is probably associated with an increased risk for HIV-1 infection and progression to AIDS [59]. Previous studies on North Indians [62,63], Whites [12] and white Spaniards [64], it has been shown that RANTES $-403 \mathrm{~A} / \mathrm{G}$ and $-28 \mathrm{C} / \mathrm{G}$ gene polymorphism does not influence the susceptibility against HIV-1 infection. In contrast RANTES - 403 A allele increases the susceptibility to HIV-1 infection in White Americans [59,65] and Han Chinese [60] while -403 $\mathrm{G}$ allele is a risk factor for HIV-1 transmission among Chinese subjects [66]. In case of RANTES In 1.1 T/C, a study has reported that In 1.1 T allele and genotype is associated with increased susceptibility to HIV-1 infection, which is in contrast with previous studies in African-Americans that RANTES In 1.1 C allele results in reduced RANTES transcription and is associated with increased susceptibility to HIV-1 infection, while in Ugandan individuals RANTES In1.1 C allele was associated with protection from death [67].

\subsection{C-C chemokine receptor-2 (CCR2)}

CCR2 is a chemokine receptor which could also function as a co-receptor for HIV-1 in some circumstances. The CCR2 gene is located on chromosome 3 , which lies within $10 \mathrm{kbp}$ from CCR5, and is in strong linkage disequilibrium with the CCR5 gene. A $G$ to $A$ transition results in the substitution of valine to isoleucine at amino acid position 64 (V64I) in the first transmembrane region of the CCR2 gene has been reported [28]. This transition has been associated with delayed disease progression to AIDS, about 24 years delay in homozygous mutant allele compared to the wild type $[28,68]$. CCR2-64I is quite common with frequencies of about $10 \%$ in Caucasians, $15 \%$ in African Americans, $17 \%$ in Hispanics and $25 \%$ in Asians, $11.76 \%$ in North Indians and $17 \%$ in South Indians $[28,38,69,70]$. A study from Thailand has reported that homozygosity for CCR2-64I is associated with reduced risk of acquiring infection among HIV1 discordant couples [71]. However, the mechanism through which CCR2-V64I confers a protective effect remains largely unknown.

\subsection{CXC chemokine receptor-4 (CXCR4)}

The highly conserved CXCR4 gene is an obvious target as CXCR4 serves as a co-receptor by X4 strains of HIV-1 to gain entry into the cells. CXCR4 gene is located on chromosome 2. CXCR4 using viruses are often identified in individuals with more advanced disease and are associated with more rapid disease progression. Screening of the entire transcription unit resulted in the detection of two rare polymorphisms but no association with progression to AIDS was found [72]. Mutations in the CXCR4 gene are generally rare and have not been implicated in HIV-1/AIDS pathogenesis [73].

\subsection{SDF-1 (stromal cell derived factor-1)}

SDF-1 also known as CXC chemokine ligand 12 (CXCL12), is the only known natural ligand for the HIV-1 coreceptor CXCR4 which inhibits infection of T cell line-tropic (T-tropic) or syncytium-inducing viruses normally found during late-stage HIV disease [74, 75] by downregulating the surface expression of the HIV-1 coreceptor, CXCR4 [76,77]. The SDF-1 gene is located on chromosome 10. A G/A transition at position 801 in the 3' untranslated region (UTR) of SDF1 have been reported. HIV-1 infected individuals homozygous for SDF-3'A have been reported to have slower progression to AIDS compared to individuals with SDF-3'G [78,79]. This mutation is common among all geographical regions of the world. Mutation may upregulate the synthesis of SDF-1, thus competitively inhibiting X4 HIV from binding. SDF-3'A is found at a frequency of $21 \%$ in Caucasians, $16 \%$ in Hispanics, 5.7\% in African Americans, 25.7\% in Asians [78] and 2.4\% in North Indians [63,80] and $11.7 \%$ in South Indians [38].

\subsection{CXC chemokine receptor-6 (CXCR6)}

CXCR6 is a G-coupled seven-transmembrane receptor, has gained interest as another portal for HIV-1 entry because it is a principal coreceptor for SIV [81-84]. CXCR6 is a secondary co-receptor for HIV that can mediate fusion of HIV-1 to CD4+ cells with HIV-1 envelope from M-tropic and dualtropic strains, and CXCR6 enhances HIV-1 infectivity, suggesting a potential role in progression of HIV-1 [83]. A polymorphism G/A at position 1469 results in a non-conservative change in codon 3 (CXCR6-E3K) of the $\mathrm{N}$ terminus of the coreceptor. Individuals homozygous or heterozygous for the CXCR6-3E allele were more likely to die a PCP 
mediated AIDS related death than were individuals homozygous for CXCR6-3K [85] and in a recent study CXCR6 was reported to be associated with long term non-progressors [86].

\section{9. $C X 3 C$ chemokine receptor-1 (CX3CRI)}

CX3CR1 is a leukocyte chemotactic and adhesion receptor for the human chemokine fractalkine. It is a minor co-rceptor for HIV-1 infection and expressed on brain. Two non-synonymous polymorphism in CX3CR1 gene have been reported, resulting in a valine to isoleucine change at position 249 (V249I) and threonine to methionine change at position 280 (T280M) [87]. The influence of CX3CR1 polymorphism on HIV-1 susceptibility and disease progression is controversial. Individuals homozygous for M280 progressed to AIDS more rapidly than other genotypes $[87,88]$. However, further studies did not confirm this observation $[63,89,90]$. Another study reported that I249 is associated with long term nonprogressors [91] whereas children with the wild type haplotype V249-T280 experienced less disease progression and central nervous system impairment, suggesting that the role of CX3CR1 in the alteration of disease progression might be the recruitment of immunomodulatory cells responsible for the control of HIV-1 [92].

\section{Conclusion}

AIDS is a multifactorial disease and is regulated by a range of different factors; therefore it is necessary to understand an individual's genetic profile in regulating the outcome of the disease. A lot of studies have been done to explore the role of genetic variants in chemokine receptors and chemokines associated with the susceptibility and progression to AIDS. The implication of these findings further needs to be explored in well defined cohorts with larger sample size and correlated with the levels of viremia and CD4 counts in Indian and other populations. The study of host genes involved in differential susceptibility and disease course is crucial for understanding of the immunopathogenesis of HIV-1 infections and for the development of immunotherapeutic and prophylactic strategies.

\section{Acknowledgement}

The Senior Research Fellowship provided by Indian Council of Medical Research, New Delhi to Mr. Animesh Chatterjee is greatly acknowledged.

\section{References}

[1] UNAIDS 2008. 2008 AIDS epidemic update. http://www. unaids.org/en/.

[2] NACO (2008). HIV/AIDS epidemiological Surveillance and Estimation report for the year 2008.

[3] W.C. Goh, J. Markee, R.E. Akridge, M. Meldorf, L. Musey, T. Karchmer, M. Krone, A. Collier, L. Corey, M. Emerman and M.J. McElrath, Protection against human immunodeficiency virus type 1 infection in persons with repeated exposure: evidence for $\mathrm{T}$ cell immunity in the absence of inherited CCR5 coreceptor defects, J Infect Dis 179(3) (1999), 548-557.

[4] F.A. Plummer, T.B. Ball, J. Kimani and K.R. Fowke, Resistance to HIV-1 infection among highly exposed sex workers in Nairobi: what mediates protection and why does it develop? Immunol Lett 66(1-3) (1999), 27-34.

[5] S. Mazzoli, D. Trabattoni, S. Lo Caputo, S. Piconi, C. Blé, F. Meacci, S. Ruzzante, A. Salvi, F. Semplici, R. Longhi, M.L. Fusi, N. Tofani, M. Biasin, M.L. Villa, F. Mazzotta and M. Clerici, HIV-specific mucosal and cellular immunity in HIV-seronegative partners of HIV-seropositive individuals, Nat Med 3(11) (1997), 1250-1257.

[6] E. Pisani, AIDS into the 21st century: some critical considerations, Reprod Health Matters 8(15) (2000), 63-76.

[7] R. Detels, Z. Liu, K. Hennessey, J. Kan, B.R. Visscher, J.M. Taylor, D.R. Hoover, C.R. Rinaldo, Jr., J.P. Phair, A.J. Saah et al., Resistance to HIV-1 infection. Multicenter AIDS Cohort Study, J Acquir Immune Defic Syndr 7(12) (1994), 1263-1269.

[8] J. Phair, L. Jacobson, R. Detels, C. Rinaldo, A. Saah, L. Schrager and A. Mum̃oz, Acquired immune deficiency syndrome occurring within 5 years of infection with human immunodeficiency virus type-1: the Multicenter AIDS Cohort Study, J Acquir Immune Defic Syndr 5(5) (1992), 490-496.

[9] Y. Cao, L. Qin, L. Zhang, J. Safrit and D.D. Ho, Virologic and immunologic characterization of long-term survivors of human immunodeficiency virus type 1 infection, $N$ Engl J Med 332(4) (1995), 201-208.

[10] G. Pantaleo, S. Menzo, M. Vaccarezza, C. Graziosi, O.J. Cohen, J.F. Demarest, D. Montefiori, J.M. Orenstein, C. Fox, L.K. Schrager et al., Studies in subjects with long-term nonprogressive human immunodeficiency virus infection, $N \mathrm{Engl}$ J Med 332(4) (1995), 209-216.

[11] S.P. Buchbinder, M.H. Katz, N.A. Hessol, P.M. O'Malley and S.D. Holmberg, Long-term HIV-1 infection without immunologic progression, AIDS 8(8) (1994), 1123-1128.

[12] H. Liu, Y. Hwangbo, S. Holte, J. Lee, C. Wang, N. Kaupp, H. Zhu, C. Celum, L. Corey, M.J. McElrath and T. Zhu, Analysis of genetic polymorphisms in CCR5, CCR2, stromal cellderived factor-1, RANTES, and dendritic cell-specific intercellular adhesion molecule-3-grabbing nonintegrin in seronegative individuals repeatedly exposed to HIV-1, J Infect Dis 190(6) (2004), 1055-1058.

[13] F. Hladik, A. Desbien, J. Lang, L. Wang, Y. Ding, S. Holte, A. Wilson, Y. Xu, M. Moerbe, S. Schmechel and M.J. McElrath, Most highly exposed seronegative men lack HIV-1specific, IFN-gamma-secreting $\mathrm{T}$ cells, J Immunol 171(5) (2003), 2671-2683.

[14] S.C. Schmechel, N. Russell, F. Hladik, J. Lang, A. Wilson, R. Ha, A. Desbien and M.J. McElrath, Immune defence against HIV-1 infection in HIV-1-exposed seronegative persons, Immunol Lett 79(1-2) (2001), 21-27.

[15] R. Akridge, F. Hladik, J. Markee, C. Alef, H. Kelley, A. Collier, A. Collier and M.J. McElrath, Cellular immunity and target 
cell susceptibility in persons with repeated HIV-1 exposure, Immunol Lett 66(1-3) (1999), 15-19.

[16] E. Gonzalez, H. Kulkarni, H. Bolivar, A. Mangano, R. Sanchez, G. Catano, R.J. Nibbs, B.I. Freedman, M.P. Quinones, M.J. Bamshad, K.K. Murthy, B.H. Rovin, W. Bradley, R.A. Clark, S.A. Anderson, R.J. O'connell, B.K. Agan, S.S. Ahuja, R. Bologna, L. Sen, M.J. Dolan and S.K. Ahuja, The influence of CCL3L1 gene-containing segmental duplications on HIV-1/AIDS susceptibility, Science 307(5714) (2005), 1434-1440.

[17] S.J. O'Brien and G.W. Nelson, Human genes that limit AIDS, Nat Genet 36(6) (2004), 565-574.

[18] W.A. Paxton, T. Dragic, R.A. Koup and J.P. Moore, The betachemokines, HIV type 1-second receptors, and exposed uninfected persons, AIDS Res Hum Retroviruses 12(13) (1996), 1203-1207.

[19] M. Dean, M. Carrington, C. Winkler, G.A. Huttley, M.W. Smith, R. Allikmets, J.J. Goedert, S.P. Buchbinder, E. Vittinghoff, E. Gomperts, S. Donfield, D. Vlahov, R. Kaslow, A. Saah, C. Rinaldo, R. Detels and S.J. O'Brien, Genetic restriction of HIV-1 infection and progression to AIDS by a deletion allele of the CKR5 structural gene. Hemophilia Growth and Development Study, Multicenter AIDS Cohort Study, Multicenter Hemophilia Cohort Study, San Francisco City Cohort, ALIVE Study, Science 273(5283) (1996), 1856-1862.

[20] P. Suresh and A. Wanchu, Chemokines and chemokine receptors in HIV infection: role in pathogenesis and therapeutics, $J$ Postgrad Med 52(3) (2006), 210-217.

[21] A. Zlotnik and O. Yoshie, Chemokines: a new classification system and their role in immunity, Immunity 12(2) (2000), 121-127.

[22] I.F. Charo and R.M. Ransohoff, The many roles of chemokines and chemokine receptors in inflammation, $N$ Engl $J$ Med 354(6) (2006), 610-621.

[23] G. Alkhatib, C. Combadiere, C.C. Broder, Y. Feng, P.E. Kennedy, P.M. Murphy and E.A. Berger, CC CKR5: a RANTES, MIP-1alpha, MIP-1beta receptor as a fusion cofactor for macrophage-tropic HIV-1, Science 272(5270) (1996), 1955-1958.

[24] H. Choe, M. Farzan, Y. Sun, N. Sullivan, B. Rollins, P.D. Ponath, L. Wu, C.R. Mackay, G. LaRosa, W. Newman, N. Gerard, C. Gerard and J. Sodroski, The beta-chemokine receptors CCR 3 and CCR 5 facilitate infection by primary HIV-1 isolates, Cell 85(7) (1996), 1135-1148.

[25] B.J. Doranz, J. Rucker, Y. Yi, R.J. Smyth, M. Samson, S.C. Peiper, M. Parmentier, R.G. Collman and R.W. Doms, A dualtropic primary HIV-1 isolate that uses fusin and the betachemokine receptors CKR-5, CKR-3, and CKR-2b as fusion cofactors, Cell 85(7) (1996), 1149-1158.

[26] M.P. Martin, M. Dean, M.W. Smith, C. Winkler, B. Gerrard, N.L. Michael, B. Lee, R.W. Doms, J. Margolick, S. Buchbinder, J.J. Goedert, T.R. O'Brien, M.W. Hilgartner, D. Vlahov, S.J. O'Brien and M. Carrington, Genetic acceleration of AIDS progression by a promoter variant of CCR5, Science 282(5395) (1998), 1907-1911.

[27] D.H. McDermott, P.A. Zimmerman, F. Guignard, C.A. Kleeberger, S.F. Leitman and P.M. Murphy, CCR5 promoter polymorphism and HIV-1 disease progression. Multicenter AIDS Cohort Study (MACS), Lancet 352(9131) (1998), 866-870.

[28] M.W. Smith, M. Dean, M. Carrington, C. Winkler, G.A. Huttley, D.A. Lomb, J.J. Goedert, T.R. O'Brien, L.P. Jacobson, R. Kaslow, S. Buchbinder, E. Vittinghoff, D. Vlahov, K. Hoots, M.W. Hilgartner and S.J. O'Brien, Contrasting genetic influence of CCR2 and CCR5 variants on HIV-1 infection and dis- ease progression. Hemophilia Growth and Development Study (HGDS), Multicenter AIDS Cohort Study (MACS), Multicenter Hemophilia Cohort Study (MHCS), San Francisco City Cohort (SFCC), ALIVE Study, Science 277(5328) (1997), 959-965.

[29] R. Liu, W.A. Paxton, S. Choe, D. Ceradini, S.R. Martin, R. Horuk et al., Homozygous defect in HIV-1 coreceptor accounts for resistance of some multiply-exposed individuals to HIV-1 infection, Cell 86(3) (1996), 367-77.

[30] M. Samson, F. Libert, B.J. Doranz, J. Rucker, C. Liesnard, C.M. Farber, S. Saragosti, C. Lapoumeroulie, J. Cognaux, C. Forceille, G. Muyldermans, C. Verhofstede, G. Burtonboy, M. Georges, T. Imai, S. Rana, Y. Yi, R.J. Smyth, R.G. Collman, R.W. Doms, G. Vassart and M. Parmentier, Resistance to HIV1 infection in caucasian individuals bearing mutant alleles of the CCR-5 chemokine receptor gene, Nature 382(6593) (1996), 722-725.

[31] J. Schinkel, M.W. Langendam, R.A. Coutinho, A. Krol, M. Brouwer and $\mathrm{H}$. Schuitemaker, No evidence for an effect of the CCR5 delta32/+ and CCR2b 64I/+ mutations on human immunodeficiency virus (HIV)-1 disease progression among HIV-1-infected injecting drug users, J Infect Dis 179(4) (1999), 825-831.

[32] G.J. Stewart, L.J. Ashton, R.A. Biti, R.A. Ffrench, B.H. Bennetts, N.R. Newcombe, E.M. Benson, A. Carr, D.A. Cooper and J.M. Kaldor, Increased frequency of CCR-5 delta 32 heterozygotes among long-term non-progressors with HIV-1 infection. The Australian Long-Term Non-Progressor Study Group, AIDS 11(15) (1997), 1833-1838.

[33] N.L. Michael, L.G. Louie and H.W. Sheppard, CCR5-delta 32 gene deletion in HIV-1 infected patients, Lancet 350(9079) (1997), 741-742.

[34] R.A. Morawetz, G.P. Rizzardi, D. Glauser, O. Rutschmann, B. Hirschel, L. Perrin, M. Opravil, M. Flepp, J. von Overbeck, M.P. Glauser, S. Ghezzi, E. Vicenzi, G. Poli, A. Lazzarin and G. Pantaleo, Genetic polymorphism of CCR5 gene and HIV disease: the heterozygous (CCR5/delta ccr5) genotype is neither essential nor sufficient for protection against disease progression. Swiss HIV Cohort, Eur J Immunol 27(12) (1997), 3223-3227.

[35] Q. Jin, J. Marsh, K. Cornetta and G. Alkhatib, Resistance to human immunodeficiency virus type 1 (HIV-1) generated by lentivirus vector-mediated delivery of the CCR5 \{Delta\} 32 gene despite detectable expression of the HIV-1 co-receptors, J Gen Virol 89 (2008), 2611-2621.

[36] L. Agrawal, Q. Jin, J. Altenburg, L. Meyer, R. Tubiana, I. Theodorou and G. Alkhatib, CCR5Delta32 protein expression and stability are critical for resistance to human immunodeficiency virus type 1 in vivo, J Virol 81(15) (2007), 8041-8049.

[37] V. Alvarez, C. López-Larrea and E. Coto, Mutational analysis of the CCR5 and CXCR4 genes (HIV-1 co-receptors) in resistance to HIV-1 infection and AIDS development among intravenous drug users, Hum Genet 102(4) (1998), 483-486.

[38] G.V. Ramana, A. Vasanthi, M. Khaja, B. Su, V. Govindaiah, L. Jin, L. Singh and R. Chakraborty, Distribution of HIV-1 resistance-conferring polymorphic alleles SDF-1-3'A, CCR264I and CCR5-Delta32 in diverse populations of Andhra Pradesh, South India, J Genet 80(3) (2001), 137-140.

[39] A. Voevodin, E. Samilchuk and S. Dashti, Frequencies of SDF-1 chemokine, CCR-5, and CCR-2 chemokine receptor gene alleles conferring resistance to human immunodeficiency virus type 1 and AIDS in Kuwaitis, J Med Virol 58(1) (1999), $54-58$. 
[40] A.O. Clegg, L.J. Ashton, R.A. Biti, P. Badhwar, P. Williamson, J.M. Kaldor and G.J. Stewart, CCR5 promoter polymorphisms, CCR5 59029A and CCR5 59353C, are under represented in HIV-1-infected long-term non-progressors. The Australian Long-Term Non-Progressor Study Group, AIDS 14(2) (2000), 103-108.

[41] T.B. Knudsen, T.B. Kristiansen, T.L. Katzenstein and J. Eugen-Olsen, Adverse effect of the CCR5 promoter -2459A allele on HIV-1 disease progression, J Med Virol 65(3) (2001), 441-444.

[42] P. An, M.P. Martin, G.W. Nelson, M. Carrington, M.W. Smith, K. Gong, D. Vlahov, S.J. O'Brien and C.A. Winkler, Influence of CCR5 promoter haplotypes on AIDS progression in African-Americans, AIDS 14(14) (2000), 2117-2122.

[43] A. Rathore, A. Chatterjee, P. Sivarama, N. Yamamoto, P.K. Singhal and T.N. Dhole, Association of CCR5-59029 A/G and CCL3L1 copy number polymorphism with HIV type 1 transmission/progression among HIV type 1-seropositive and repeatedly sexually exposed HIV type 1-seronegative North Indians, AIDS Res Hum Retroviruses 25(11) (2009), 11491156.

[44] P.J. Easterbrook, T. Rostron, N. Ives, M. Troop, B.G. Gazzard and S.L. Rowland-Jones, Chemokine receptor polymorphisms and human immunodeficiency virus disease progression, $J$ Infect Dis 180(4) (1999), 1096-1105.

[45] G. Kaur, P. Singh, C.C. Rapthap, N. Kumar, M. Vajpayee, S.K. Sharma, A. Wanchu and N.K. Mehra, Polymorphism in the CCR5 gene promoter and HIV-1 infection in North Indians, Hum Immunol 68(5) (2007), 454-461.

[46] T.J. Wasik, J. Smoleń, P. Kruszyński, J. Bratosiewicz-Wasik and M. Beniowski, Effects of CCR5-delta32, CCR2-64I and SDF-1-3'A polymorphic alleles on human immunodeficiency virus 1 (HIV-1) infection in the Polish population, Wiad Lek 58(9-10) (2005), 500-507.

[47] F. Roman, N. Franck, C. Burgy, J. Servais, J.M. Zimmer, J. Mossong, P. Goubau, F. Schneider, R. Hemmer and J.C. Schmit, Prevalence of HIV co-receptor polymorphisms in HIV-infected patients and uninfected volunteers in Luxembourg, HIV Clin Trials 3(3) (2002), 195-201.

[48] G.C. John, T. Bird, J. Overbaugh, R. Nduati, D. MboriNgacha, T. Rostron, T. Dong, L. Kostrikis, B. Richardson and S.L. Rowland-Jones, CCR5 promoter polymorphisms in a Kenyan perinatal human immunodeficiency virus type 1 cohort: association with increased 2-year maternal mortality, $J$ Infect Dis 184(1) (2001), 89-92.

[49] S.G. Irving, P.F. Zipfel, J. Balke, O.W. McBride, C.C. Morton, P.R. Burd, U. Siebenlist and K. Kelly, Two inflammatory mediator cytokine genes are closely linked and variably amplified on chromosome 17q, Nucleic Acids Res 18(11) (1990), 3261-3270.

[50] P. Menten, A. Wuyts and J. Van Damme, Macrophage inflammatory protein-1, Cytokine Growth Factor Rev 13(6) (2002), 455-481.

[51] T. Nakajima, H. Ohtani, T. Naruse, H. Shibata, J.I. Mimaya, H. Terunuma and A. Kimura, Copy number variations of CCL3L1 and long-term prognosis of HIV-1 infection in asymptomatic HIV-infected Japanese with hemophilia, Immunogenetics 59(10) (2007), 793-798; Nat Med 4(3) (1998), 350-353.

[52] W. Shao, J. Tang, W. Song, C. Wang, Y. Li, C.M. Wilson and R.A. Kaslow, CCL3L1 and CCL4L1: variable gene copy number in adolescents with and without human immunodeficiency virus type 1 (HIV-1) infection, Genes Immun 8(3) (2007), 224-231.
[53] J.R. Townson, L.F. Barcellos and R.J. Nibbs, Gene copy number regulates the production of the human chemokine CCL3L1, Eur J Immunol 32(10) (2002), 3016-3026.

[54] E. Pilotti, L. Elviri, E. Vicenzi, U. Bertazzoni, M.C. Re, S. Allibardi, G. Poli and C. Casoli, Postgenomic up-regulation of CCL3L1 expression in HTLV-2-infected persons curtails HIV-1 replication, Blood 109(5) (2007), 1850-1856.

[55] H. Moriuchi, M. Moriuchi and A.S. Fauci, Nuclear factorkappa B potently up-regulates the promoter activity of RANTES, a chemokine that blocks HIV infection, J Immunol 158(7) (1997), 3483-3491.

[56] F. Cocchi, A.L. DeVico, A. Garzino-Demo, S.K. Arya, R.C. Gallo and P. Lusso, Identification of RANTES, MIP-1 alpha, and MIP-1 beta as the major HIV-suppressive factors produced by CD8+ T cells, Science 270(5243) (1995), 1811-1815.

[57] F. Arenzana-Seisdedos, J.L. Virelizier, D. Rousset, I. ClarkLewis, P. Loetscher, B. Moser and M. Baggiolini, HIV blocked by chemokine antagonist, Nature 383(6599) (1996), 400.

[58] M. Mack, B. Luckow, P.J. Nelson, J. Cihak, G. Simmons, P.R. Clapham, N. Signoret, M. Marsh, M. Stangassinger, F. Borlat, T.N. Wells, D. Schlöndorff and A.E. Proudfoot, Aminooxypentane-RANTES induces CCR5 internalization but inhibits recycling: a novel inhibitory mechanism of HIV infectivity, J Exp Med 187(8) (1998), 1215-1224.

[59] P. An, G.W. Nelson, L. Wang, S. Donfield, J.J. Goedert, J. Phair, D. Vlahov, S. Buchbinder, W.L. Farrar, W. Modi, S.J. O'Brien and C.A. Winkler, Modulating influence on HIV/AIDS by interacting RANTES gene variants, Proc Natl Acad Sci U S A 99(15) (2002), 10002-10007.

[60] H. Liu, D. Chao, E.E. Nakayama, H. Taguchi, M. Goto, X. Xin, J.K. Takamatsu, H. Saito, Y. Ishikawa, T. Akaza, T. Juji, Y. Takebe, T. Ohishi, K. Fukutake, Y. Maruyama, S. Yashiki, S. Sonoda, T. Nakamura, Y. Nagai, A. Iwamoto and T. Shioda, Polymorphism in RANTES chemokine promoter affects HIV1 disease progression, Proc Natl Acad Sci U S A 96(8) (1999), $4581-4585$.

[61] R.G. Nickel, V. Casolaro, U. Wahn, K. Beyer, K.C. Barnes, B.S. Plunkett, L.R. Freidhoff, C. Sengler, J.R. Plitt, R.P. Schleimer, L. Caraballo, R.P. Naidu, P.N. Levett, T.H. Beaty and S.K. Huang, Atopic dermatitis is associated with a functional mutation in the promoter of the C-C chemokine RANTES, J Immunol 164(3) (2000), 1612-1616.

[62] A. Rathore, A. Chatterjee, P. Sivarama, N. Yamamoto, P.K. Singhal and T.N. Dhole, Association of RANTES - 403 G/A, $-28 \mathrm{C} / \mathrm{G}$ and In1.1 T/C polymorphism with HIV-1 transmission and progression among North Indians, J Med Virol 80(7) (2008), 1133-1141.

[63] P. Suresh, A. Wanchu, R.K. Sachdeva and A. Bhatnagar, Gene polymorphisms in CCR5, CCR2, CX3CR1, SDF-1 and RANTES in exposed but uninfected partners of HIV-1 infected individuals in North India, J Clin Immunol 26(5) (2006), 476-484.

[64] F. Vidal, J. Peraire, P. Domingo, M. Broch, M. Cairó, E. Pedrol, M. Montero, C. Viladés, C. Gutiérrez, M.A. Sambeat, A. Fontanet, D. Dalmau, E. Deig, H. Knobel, J.J. Sirvent, C. Richart, S. Veloso, M. Saumoy, M. López-Dupla, M. Olona, J. Cadafalch, M. Fuster, A. Ochoa, A. Soler, A. Guelar and J. Gonzälez, Chemokines and Long-Term Nonprogressive HIV01 Infection Study Group. Polymorphism of RANTES chemokine gene promoter is not associated with long-term nonprogressive HIV-1 infection of more than 16 years, $J$ Acquir Immune Defic Syndr 41(1) (2006), 17-22.

[65] D.H. McDermott, M.J. Beecroft, C.A. Kleeberger, F.M. AlSharif, W.E. Ollier, P.A. Zimmerman, B.A. Boatin, S.F. Leit- 
man, R. Detels, A.H. Hajeer and P.M. Murphy, Chemokine RANTES promoter polymorphism affects risk of both HIV infection and disease progression in the Multicenter AIDS Cohort Study, AIDS 14(17) (2000), 2671-2678.

[66] X.Y. Zhao, S.S. Lee, K.H. Wong, K.C. Chan, S. Ma, W.C. Yam, K.Y. Yuen, M.H. Ng and B.J. Zheng, Effects of single nucleotide polymorphisms in the RANTES promoter region in healthy and HIV-infected indigenous Chinese, Eur J Immunogenet 31(4) (2004), 179-183.

[67] G.S. Cooke, K. Tosh, P.A. Ramaley, P. Kaleebu, J. Zhuang, J.S. Nakiyingi, C. Watera, C.F. Gilks, N. French, J.A. Whitworth and A.V. Hill, A polymorphism that reduces RANTES expression is associated with protection from death in HIVseropositive Ugandans with advanced disease, $J$ Infect Dis 194(5) (2006), 666-669.

[68] L.G. Kostrikis, Y. Huang, J.P. Moore, S.M. Wolinsky, L. Zhang, Y. Guo, L. Deutsch, J. Phair, A.U. Neumann and D.D. Ho, A chemokine receptor CCR2 allele delays HIV-1 disease progression and is associated with a CCR5 promoter mutation.

[69] G. Kaur, P. Singh, N. Kumar, C.C. Rapthap, G. Sharma, M. Vajpayee, N. Wig, S.K. Sharma and N.K. Mehra, Distribution of CCR2 polymorphism in HIV-1-infected and healthy subjects in North India, Int J Immunogenet 34(3) (2007), 153-156.

[70] M. Carrington, G. Nelson and S.J. O’Brien, Considering genetic profiles in functional studies of immune responsiveness to HIV-1, Immunol Lett 79(1-2) (2001), 131-140.

[71] S. Louisirirotchanakul, H. Liu, A. Roongpisuthipong, E.E. Nakayama, Y. Takebe, T. Shioda and C. Wasi, Genetic analysis of HIV-1 discordant couples in Thailand: association of CCR2 64I homozygosity with HIV-1-negative status, J Acquir Immune Defic Syndr 29(3) (2002), 314-315.

[72] O.J. Cohen, S. Paolucci, S.M. Bende, M. Daucher, H. Moriuchi, M. Moriuchi, C. Cicala, R.T. Davey, Jr., B. Baird and A.S. Fauci, CXCR4 and CCR5 genetic polymorphisms in long-term nonprogressive human immunodeficiency virus infection: lack of association with mutations other than CCR5Delta32, J Virol 72(7) (1998), 6215-6217.

[73] D.C. Petersen, R.H. Glashoff, S. Shrestha, J. Bergeron, A. Laten, B. Gold, E.J. van Rensburg, M. Dean and V.M. Hayes, Risk for HIV-1 infection associated with a common CXCL12 (SDF1) polymorphism and CXCR4 variation in an African population, J Acquir Immune Defic Syndr 40(5) (2005), 521526.

[74] C.C. Bleul, M. Farzan, H. Choe et al., The lymphocyte chemoattractant SDF-1 is a ligand for LESTR/fusin and blocks HIV-1 entry, Nature 382 (1996), 829-833.

[75] E. Oberlin, A. Amara, F. Bachelerie et al., The CXC chemokine SDF-1 is the ligand for LESTR/fusin and prevents infection by T-cell-line-adapted HIV-1, Nature 382 (1996), 833-835.

[76] A. Amara, S.L. Gall, O. Schwartz et al., HIV coreceptor downregulation as antiviral principle: SDF-1 alpha-dependent internalisation of the chemokine receptor CXCR4 contributes to inhibition of HIV replication, J Exp Med 186 (1997), 139-146.

[77] N. Signoret, J. Oldridge, A. Pelchen-Matthews et al., Phorbol esters and SDF-1 induce rapid endocytosis and down modulation of the chemokine receptor CXCR4, J Cell Biol 139 (1997), 651-664.

[78] C. Winkler, W. Modi, M.W. Smith, G.W. Nelson, X. Wu, M. Carrington, M. Dean et al., Genetic restriction of AIDS pathogenesis by an SDF-1 chemokine gene variant. ALIVE Study, Hemophilia Growth and Development Study (HGDS), Multicenter AIDS Cohort Study (MACS), Multicenter Hemophilia
Cohort Study (MHCS), San Francisco City Cohort (SFCC) Science 279(5349) (1998), 389-393.

[79] H. Hendel, N. Hénon, H. Lebuanec, A. Lachgar, H. Poncelet, S. Caillat-Zucman, C.A. Winkler, M.W. Smith, L. Kenefic, S. O'Brien, W. Lu, J.M. Andrieu, D. Zagury, F. Schächter, J. Rappaport and J.F. Zagury, Distinctive effects of CCR5, CCR2, and SDF1 genetic polymorphisms in AIDS progression, J Acquir Immune Defic Syndr 19(4) (1998), 381-386.

[80] N. Ramamoorti, J. Kumarvelu, G.K. Shanmugasundaram, K. Rani and A.C. Banerjea, High frequency of $\mathrm{G}$ to A transition mutation in the stromal cell derived factor- 1 gene in India, a chemokine that blocks HIV-1 (X4) infection: multiple proteins bind to 3'-untranslated region of SDF-1 RNA, Genes Immun 2(7) (2001), 408-410.

[81] M. Matloubian, A. David, S. Engel, J.E. Ryan and J.G. Cyster, A transmembrane CXC chemokine is a ligand for HIVcoreceptor Bonzo, Nat Immunol 1 (2000), 298-304.

[82] H.K. Deng, D. Unutmaz, V.N. Kewalramani and D.R. Littman, Expression cloning of new receptors used by simian and human immunodeficiency viruses, Nature 388 (1997), 296-300.

[83] F. Liao, G. Alkhatib, K.W. Peden et al., STRL33, A novel chemokine receptor-like protein, functions as a fusion cofactor for both macrophage-tropic and T cell line-tropic HIV-1, J Exp Med 185 (1997), 2015-2023.

[84] M. Loetscher, A. Amara, E. Oberlin et al., TYMSTR, a putative chemokine receptor selectively expressed in activated $\mathrm{T}$ cells, exhibits HIV-1 coreceptor function, Curr Biol 7 (1997), 652-660.

[85] P. Duggal, P. An, T.H. Beaty, S.A. Strathdee, H. Farzadegan, R.B. Markham, L. Johnson, S.J. O'Brien, D. Vlahov and C.A. Winkler, Genetic influence of CXCR6 chemokine receptor alleles on PCP-mediated AIDS progression among African Americans, Genes Immun 4 (2003), 245-250.

[86] S. Limou, C. Coulonges, J.T. Herbeck, D. van Manen et al., Multiple-cohort genetic association study reveals CXCR6 as a new chemokine receptor involved in long-term nonprogression to AIDS, J Infect Dis 202(6) (2010), 908-915.

[87] S. Faure, L. Meyer, D. Costagliola, C. Vaneensberghe, E. Genin, B. Autran, J.F. Delfraissy, D.H. McDermott, P.M. Murphy, P. Debré, I. Théodorou and C. Combadière, Rapid progression to AIDS in HIV+ individuals with a structural variant of the chemokine receptor CX3CR1, Science 287(5461) (2000), 2274-2277.

[88] S. Faure, L. Meyer, E. Genin, P. Pellet, P. Debré, I. Théodorou and C. Combadière, SEROCO Study Group. Deleterious genetic influence of CX3CR1 genotypes on HIV-1 disease progression, J Acquir Immune Defic Syndr 32(3) (2003), 335337.

[89] D.H. McDermott, J.S. Colla, C.A. Kleeberger, M. Plankey, P.S. Rosenberg, E.D. Smith, P.A. Zimmerman, C. Combadière, S.F. Leitman, R.A. Kaslow, J.J. Goedert, E.A. Berger, T.R. O'Brien and P.M. Murphy, Genetic polymorphism in CX3CR1 and risk of HIV disease, Science 290(5499) (2000), 2031.

[90] D. Kwa, B. Boeser-Nunnink and H. Schuitemaker, Lack of evidence for an association between a polymorphism in CX3CR1 and the clinical course of HIVinfection or virus phenotype evolution, AIDS 17(5) (2003), 759-761.

[91] F. Vidal, C. Viladés, P. Domingo, M. Broch, E. Pedrol, D. Dalmau, H. Knobel, J. Peraire, C. Gutiérrez, M.A. Sambeat, A. Fontanet, E. Deig, M. Cairó, M. Montero, C. Richart and S. Mallal, Chemokines LTNP Study Group. Spanish HIV-1infected long-term nonprogressors of more than 15 years have an increased frequency of the CX3CR1 249I variant allele, $J$ Acquir Immune Defic Syndr 40(5) (2005), 527-531. 
[92] K.K. Singh, M.D. Hughes, J. Chen and S.A. Spector, Genetic polymorphisms in CX3CR1 predict HIV-1 disease progres- sion in children independently of CD4+ lymphocyte count and HIV-1 RNA load, J Infect Dis 191(11) (2005), 1971-1980. 


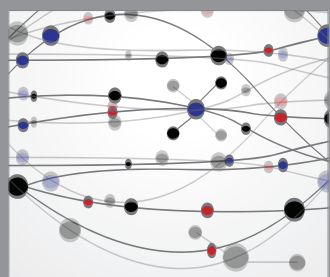

The Scientific World Journal
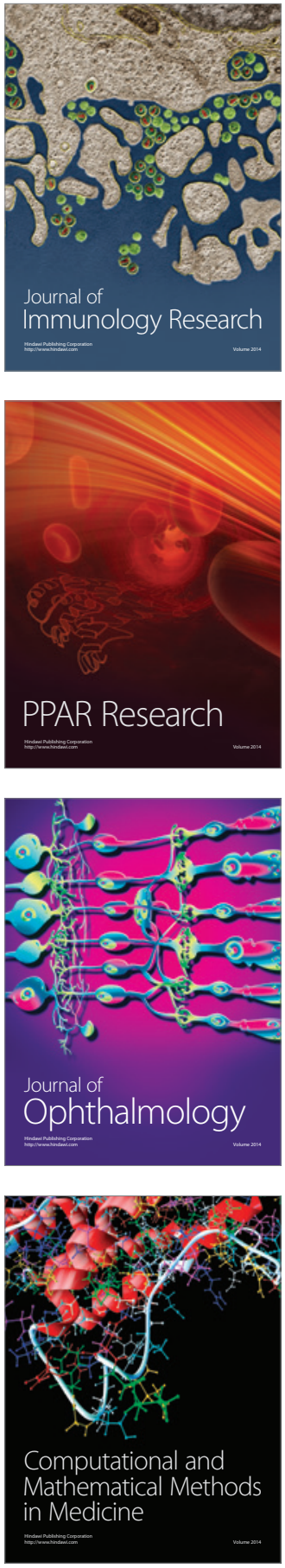

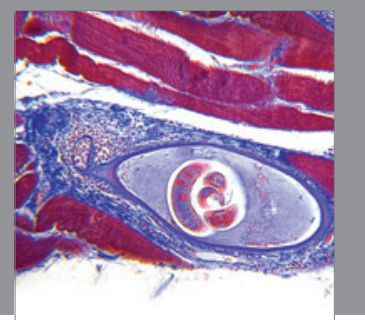

Gastroenterology

Research and Practice
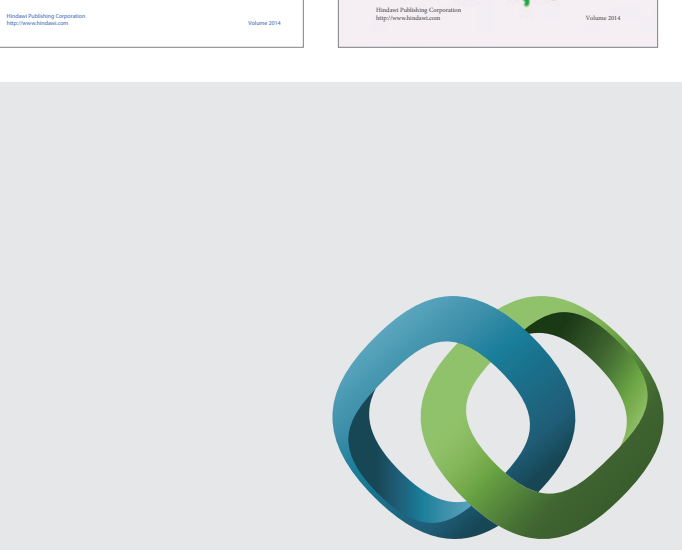

\section{Hindawi}

Submit your manuscripts at

http://www.hindawi.com
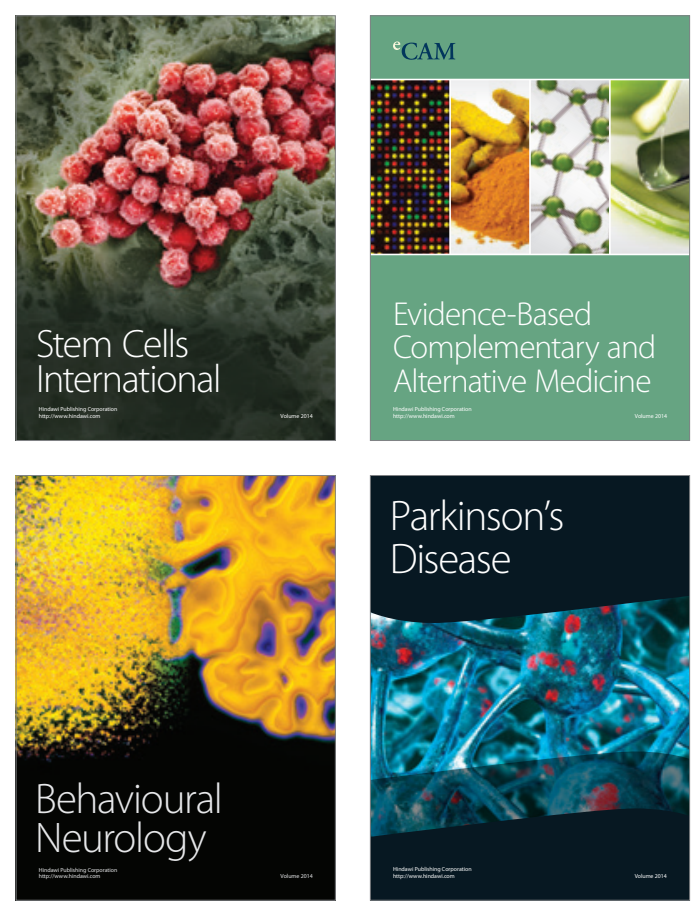

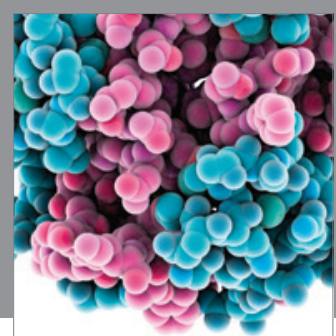

Journal of
Diabetes Research

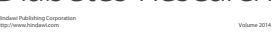

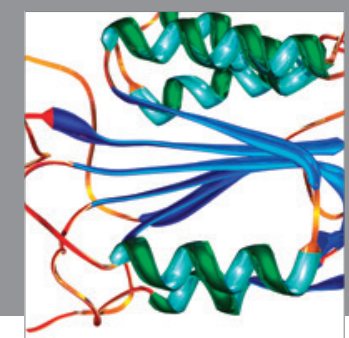

Disease Markers
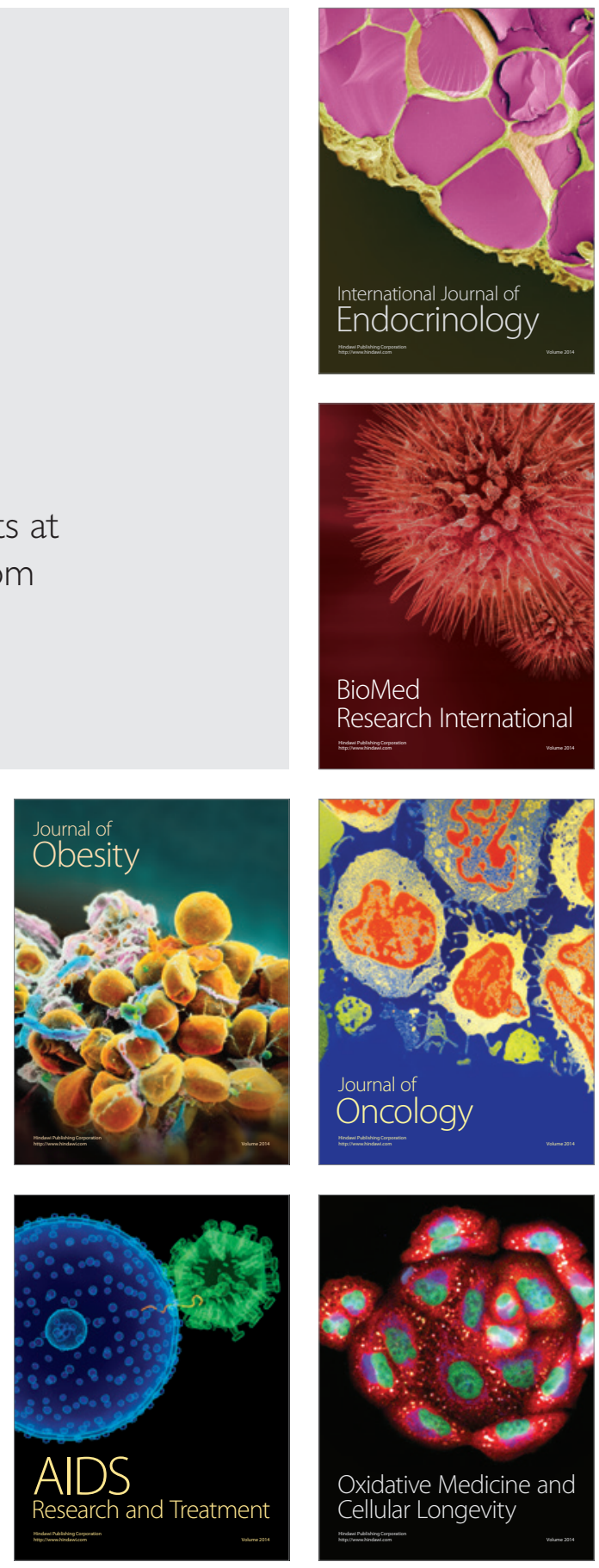